\title{
Anchoring energy efficiency information in households' everyday projects: Peoples' understanding of renewable heating systems
}

Charlotta Isaksson and Kajsa Ellegård

\author{
Linköping University Post Print
}

Tweet

N.B.: When citing this work, cite the original article.

The original publication is available at www.springerlink.com:

Charlotta Isaksson and Kajsa Ellegård, Anchoring energy efficiency information in households' everyday projects: Peoples' understanding of renewable heating systems, 2015, Energy Efficiency, (8), 2, 353-364.

http://dx.doi.org/10.1007/s12053-014-9299-x

Copyright: Springer Verlag (Germany)

http://www.springerlink.com/?MUD=MP

Postprint available at: Linköping University Electronic Press

http://urn.kb.se/resolve?urn=urn:nbn:se:liu:diva-113950 


\title{
Anchoring energy efficiency information in households' everyday
}

\author{
projects: Peoples' understanding of renewable heating systems
}

\author{
Charlotta Isaksson ${ }^{1, *}$, Kajsa Ellegård ${ }^{2}$ \\ ${ }^{1}$ Department of Social and Behavioural Studies, University West, SE-461 86 Trollhättan,
} Sweden

${ }^{2}$ Department of Thematic Studies, Technology and Social Change, Linköping University, SE-

58183 Linköping, Sweden

\begin{abstract}
In general energy conservation information policy instruments yield poor results. This article claims that the contents of such policy must be better adapted to household members' everyday life experiences in order to capture their interest and transform information into action. The article elaborates on how to ground energy policy information in the everyday doings and strivings of households. Using two time-geographical concepts, i.e., activity and project, we investigate how people understand and define their energy-related activities as parts of overarching everyday projects with a focus on the constraints on energy conservation. The analysis is empirically based on interview data from a case study of households' use of renewable heating technologies. The results illustrate how peoples' heating activities are related to everyday projects such as reducing environmental impact; comfort for a convenient daily life; the household budget balance, , learning about and/or maintaining home technologies; and hobbies.
\end{abstract}

One conclusion is that information instruments focusing solely on one or two such projects might hamper the translation from information to action and also limit the number of people interested in or able to access the information. Another conclusion is that the growing use of energy-efficient technologies might influence new habits and perceptions of the everyday use of energy, making common economic motives for saving energy less useful. Anchoring energy-related information and support in the everyday activities and projects of households would facilitate the translation process. If this is achieved, information could prove a useful instrument in the broader reorganization of societal institutions in a sustainable direction.

Keywords Energy use information, Household context, Time-geography, Translation, Renewable heating systems

\footnotetext{
${ }^{*}$ Corresponding author. Tel.: +46520223713; fax: +46520223099.

E-mail address: charlotta.isaksson@hv.se.
} 


\section{Introduction}

Ecological modernization entails reorganizing societal institutions in a more sustainable direction (Dryzek 2005). In the strongest sense, this involves broadranging changes throughout society, including in the household sector (Spaargaren 2000), ${ }^{1}$ to make people more receptive to ecological concerns (Christoff 1996). Regarding lowering energy consumption, environmental reorganization implies that household members must reconsider their everyday activities that use energy-related technologies (Spaargaren and Van Vliet 2000). In fact, and as repeatedly

demonstrated in this journal, energy-efficient behaviour is as important as are energy-efficient technologies in reducing household energy consumption (GramHanssen 2013), indicating the importance of incorporating end users' activities, knowledge, and preferences in energy efficiency initiatives (e.g., Bartiaux 2008; Darby 2006; Jonsson et al. 2011; Pyrko and Darby 2011). Policy instruments designed to inform and support household members' energy-related activities ought to play a key role in facilitating such incorporation and induce people to make their activities more energy efficient. Providing information on how to reduce energy use, delivered, for example, via pamphlets, advertisements, or product labelling, is one of several top-down policy instruments promoting more careful resource use. ${ }^{2}$

According to Lindén et al. (2006), these instruments are "formulated, established, controlled and evaluated by an authority on behalf of national policy decisions" ( $p$. 1920).

However, research demonstrates that common policy information instruments, such as energy-conservation information campaigns targeting households (Gyberg and Palm 2009; Lindén et al. 2006), produce limited effects in terms of reduced energy use (Abrahamse et al. 2005). Although household members' energy awareness might increase because of the campaign, they do not necessarily act in more energyefficient ways (Erickson 1997; Palmborg 1986; Skill 2008). One reason for this is that the information supplied in information campaigns is not translated properly into a message that fits the everyday life context of household members (Bartiaux 2008), i.e., it does not correspond to "people's own realities and concerns" (Winther and Ericson 2013, p. 383). The problem of information translation does not primarily concern household members' ability to understand a message as such. Instead, the problem is whether household members can accommodate, prioritize, and implement the message in everyday life situations. Accordingly, Darby (2006) urges the redeveloping of information policy instruments to emphasize the development of information and support that better fit households' everyday life context.

The design and message of information policy instruments are often based on evidence regarding how individual energy use is associated with general socioeconomic factors, the evidence being obtained using mainstream social research

\footnotetext{
${ }^{1}$ A household consists of one or more individuals living together in a dwelling. The household as such is a category, not an actor in its own right. The individual household members are the actors who influence what is measured at the household level.

${ }^{2}$ Lindén et al. (2006) distinguish four categories of relevant policy instruments: information, economic (e.g., taxes, pricing, and emission trading), administrative (e.g., legislated regulations), and physical (e.g., technical improvements intended to influence energy conservation). These instruments can be combined in various ways; for example, smart meters are a physical instrument that can be used to inform households about their energy use.
} 
approaches. Relationships between income and energy use are particularly recognized; for example, low-income households use significantly less energy than do high-income households (e.g., Druckman and Jackson 2008; Gatersleben et al. 2002), are less likely to change their heating system (Mahapatra and Gustavsson 2009), and report different motives for saving energy (Bruel and Hoekstra 2005). In addition, factors such as age, housing type (Lindén et al. 2006), and household composition (Druckman and Jackson 2008) are associated with differences in energy use. With few exceptions, such broad socio-economic categorizations and explanations consider only parts of people's daily experiences. They pay less or no attention to the context in which energy is used or how people actually think, act, and interact when using energy-related technology in the complex combinations of everyday activities and situations.

Another complication derives from the fact that energy use and its environmental impacts are "invisible" and deeply embedded in daily activities such as transportation, cooking, cleaning, washing, and maintaining comfort (Aune 2007; Gatersleben et al. 2002; Shove 2003; Wilhite and Lutzenhiser 1999). From a shortterm perspective, it is primarily the utility and performance of these activities and services that occupy people's attention, and not the embedded use of energy (Shove 2003) - at least as long as the energy cost is reasonable. The main practical purpose is to achieve results from various functions and services, not to save energy (Lindén et al. 2006). Accordingly, there is a need to emphasize people's daily doings and strivings, i.e., household members' daily activities and projects in order for policy makers to develop information and support that better fit households' everyday life context.

Against this background, the contribution of the article is to discuss what might hamper the translation processes of energy-related information and, in turn, what should be considered when developing energy advice and support for households. By using two time-geographical concepts, i.e., activity and project (Hägerstrand 1985), this article departure from and investigates how people understand and define energy-related activities as parts of everyday projects.

The analysis is on one hand based on a Swedish interview study of household members' perceptions of their newly purchased heating systems and on the other hand on research concerning household energy use behavior, in particular the domestic use of heating systems. The examination of household heating technology use is justified by the fact that these technologies demands a large amount of energy and should be an obvious target of energy policy (e.g., Gatersleben et al. 2002; Wilhite and Nilsson 2008). A common policy goal in this area is to induce people to convert their systems to run on renewable resources (SOU 2008; Swedish Parliament 2009), which is precisely what the households interviewed here have done. In this sense, these households are aligned with the targets set by Swedish authorities, but what about their everyday use of their new technologies? Thus, the discussion in particular revolves around the subsequent use of energy efficiency improvements in the building sector.

Next, the analytical concepts and empirical data are described, after which the result of the investigation is presented. The conclusions address the value of anchoring energy-related information and support in the everyday activities and projects of 
households and provide additional guidelines for developing energy information instruments.

\section{Analytical concepts}

Analysing everyday life with a focus on sustainability calls for a theoretical approach that takes account of the manifold variety of people's daily doings, including those using energy. The time-geographic approach, ${ }^{3}$ including the concepts of activities and projects, is useful for this purpose. Time-geography highlights activities, some of which are ingrained in people's daily, habitual doings and thereby often taken for granted. A project is defined as a set of activities that aims at reaching a specific goal. People combine activities to realize projects with various goals, time perspectives, and degrees of complexity. Projects might be initiated by members of formal or informal organizations or by single individuals (Ellegård 1999, 2001). Activities related to long-term projects (e.g., earning income, obtaining education, and raising children) and shorter-term projects (e.g., preparing dinner, holding a party, buying a new refrigerator, and doing the laundry) mix with each other in the course of the day. Long-term projects may contain short-term projects as components; for example, raising children includes making them familiar with daily tasks, such as doing the laundry and preparing dinner. Projects are future oriented and address goals, and people must perform various activities to realize them.

Several methods can be used to attain knowledge about peoples' performance of the activities needed to realize their projects. Interviewing people about their everyday lives and how they usually perform their everyday activities is one frequently used approach that also yields information about the constraints people face.

\section{Methods and empirical data}

We use data about people's understanding of their heating systems and related activities derived from 24 in-depth interviews conducted in 2010 with Swedish homeowners who had recently (on average, within one year) converted either to bedrock heat pumps or district heating (12 interviews each). These two types of heating systems are popular among Swedish households (Mahapatra and Gustavsson 2008; Mårtensson and Fredriksen 2005) and both bedrock heat pumps and district heating are classified as powered by renewable energy in Sweden, although they use different energy sources and production methods. A bedrock heat pump uses heat from solar energy stored in bedrock and groundwater near the house. The heat is collected from a hole drilled approximately 90-200 metres into the ground by means of liquid circulating in a collector pipe. Bedrock heat pump is a small scale energy system, and is usually an investment by the individual household, located on their own property while district heating is an investment made by a company of a municipality. District heating is a networked infrastructure to which a household are able to connect (if the network is present in the area where they live). A central power plant produce heated water that is transported to the heated buildings via wellinsulated pipes. In Sweden, these plants often use biofuels, energy from waste incineration, or waste energy from industry. With both systems, the heat is

\footnotetext{
${ }^{3}$ Time-geography was developed by Professor Torsten Hägerstrand at Lund University, Sweden. He introduced the approach in the late 1960s and has, with his research group, developed the concept since then (Hägerstrand, 1970, 1985).
} 
distributed inside the house by means of a water-based heating system and is normally used to meet both space heating and hot water requirements.

Interviews were conducted in or near a small (bedrock heat pump study) or large (district heating study) Swedish town. The respondents were 30-80 years old and the households contained one to five members. In total, 26 respondents, 21 men and five women, participated. In households with more than one adult, the one who usually dealt with the heating system was interviewed. Thus among the respondents, it was more men than women who had responsibility for and managed the technology for heating. This pattern is also found in other studies (Henning 2005; Isaksson 2009). Most interviews took place at the household members' homes (mostly detached, and a few semi-detached) and often involved a short heating system demonstration in which the respondent showed the location of the system and the basic settings/features that he or she was familiar with. The interviews, which lasted 40 minutes to two hours, were audio-recorded and later transcribed for analysis. The interview guide emphasized how the household members acquired, appropriated, and used these technologies and the various tools and means of social support employed in the process.

The investigation was conducted by qualitative thematic analyses, in which the researcher, based on the aim of the study, analyses and present various themes identified in the empirical data. In this article, the purpose of the thematic analysis was to investigate projects in daily life in which people engage and perform activities that relate to their new heating system. The identification of the various projects stems from the respondents discussion about the appropriation, perception and use of the technology, with a focus on how the new technology in various ways became part of their everyday life. Quotations are used to underline how people reason (or not) about energy in their everyday projects and research literature was used to further explore the projects. Quoted respondents are referred to by pseudonyms accompanied by the initials "BH" for the bedrock heat pumps and "DH" for the district heat supply (see appendix).

In a thematic analysis the focus is on the themes identified and not primarily on individual characteristics or quantifications of the respondents. It is important to see what kinds of projects and activities that appears in the thematic analysis of the empirical material even if sometimes just a few persons are concerned with specific activities. Identifying and discussing the variation of projects and activities informs that information and support preferably should not be formulated in the same way in all situations and to all people.

Thus, we have made a non-conventional investigation based on thematic analysis of interviews and literature and we have taken another point of departure than the commonly utilized socioeconomic variables. We have searched for other ways to construct what might serve as a base for grouping households, and in the article we try to use "everyday projects" and "activities" related to these. In this case the projects will have qualitatively different meanings. One of our main points of departures is that people and households differ in terms of their daily doings - and that is why it is important to understand in what ways and use these differences in activities as a ground for improving energy conservation information rather than looking upon the differences as something problematic. 


\section{Heating-related activities and their anchoring in various everyday projects}

Imagine someone standing in front of a heating system thermostat, engaged in the ordinary activity of adjusting the indoor temperature. How can this activity be interpreted? What is going on here? As Goffman (1986, p. 21) points out, individuals "locate, perceive, identify and label" concrete occurrences, which thereby function as resources guiding and organizing how they perform activities. How the person, interacting with the heating system, understands and defines the interaction more or less consciously influences how he or she acts, which in the end is decisive for the energy use.

Individuals do not define their situations in a vacuum. Seen from a time-geographical perspective, their definitions differ because their activities are parts of different everyday projects. At a general level, a project guides the individual's activities towards a goal, while at a concrete level, it is the individual and the circumstances embedded in each situation that determine what project is most important at a given time and, hence, what activities to perform. In this section, we draw on individuals' descriptions of how they understand their activities when interacting with their heating systems in light of some common household projects. ${ }^{4}$ The identified projects treated are environmental concerns; comfort; household economy; learning how to handle machines and hobbies.

\subsection{Activities related to environmental concerns}

In Swedish single-family houses, approximately $75 \%$ of the total energy consumed is used to supply heat and hot water. From an energy policy perspective, heating systems are often defined by their environmental impact, and policy goals are set both to conserve heat and to induce people to convert their systems to run on renewable resources (SOU 2008; Swedish Parliament 2009). In the interview study, environmental concern was not cited as a very important issue when it came to the daily use of the renewable heating system. Although there were exceptions, such as one respondent who stated that "I try to keep the indoor temperature down to reduce the environmental impact" (Simon DH), activities related to the overall project of reducing environmental impact were instead connected to the purchase of the heating system than to its use. The environment was not the main reason for converting to a renewable heating system (see also Mahapatra and Gustavsson 2008), but combating environmental problems was felt by many to be a good cause that strengthened a choice made for other reasons. One respondent who converted from oil to district heating said that it felt important to do something for the environment:

Now we are no longer bad polluter guys since we no longer use oil [for heating] or emit a lot of harmful carbon dioxide and sulphur and whatever else it may be. (Eva DH)

\footnotetext{
${ }^{4}$ In this limited description, we have not considered the other activities (in addition to those concerning the heating system) of which each project is constituted. For example, creating indoor comfort, besides involving the heating system, is realized by means of activities such as putting on clothes, closing doors, and lighting candles and by using material objects such as building envelopes, all of which point towards alternative or complementary ways of performing the project. Such knowledge is relevant to developing/constructing information and support as well as to encouraging alternative or complementary ways of performing projects.
} 
This statement demonstrates a strong confidence in the environmental benefits of the newly purchased system (especially compared with the previous system), and it is almost as though they believe the environmental problems with heating have all been solved merely by buying the new technology. In the study, this confidence seems to be one of the main reasons for the lack of environmental concerns when it comes to the actual use of the heating systems. In fact, there is even a risk that converting to a renewable system could lead to more wasteful environmental behaviour:

This year I have allowed myself to have it very hot. I do not really know how hot, but I have certainly had it at 21 degrees, more than 20 degrees. Perhaps I was trying to keep it at 19 before ... Now that I have district heating, now I can have it hot! (Rita DH)

In the literature, this is discussed under the rubric of "rebound effects" (e.g., Herring and Sorell 2009), that is, various household behaviours that reduce the extent of the potential energy savings, generating criticism of an exclusive focus on energyefficient technology at the expense of energy-conserving behaviour (e.g., Herring 2006, Shove 2004, Gyberg and Palm 2009).

In fact, the strong confidence in the environmental benefits of energy efficient technology and the tendency to use these technologies more wastefully demonstrates the importance of highlighting information on energy conservation behaviour when promoting energy-efficient technology. Households with old habits resulting in low energy consumption should be encouraged to maintain these habits in order to increase the reduction of energy use caused by the more energy efficient heating technology. Therefore, it is necessarily not a question for energy policy to change energy behavior of such households. Instead of messages urging them to develop new habits, in such cases, their old habits should actually be preserved.

\subsection{Activities stemming from social norms of comfort}

As Shove (2003) argues, people are oriented to the services, such as comfort and cleanliness, provided by energy-intensive technologies, not to the energy they use. This was demonstrated in the present study when household members regarded interacting with the heating system as involvement in the project of creating a comfortable indoor environment. If the indoor temperature is inappropriate, the activity of adjusting the temperature setting is one way of improving the comfort. Whether a comfortable temperature means lowering or raising the temperature setting depends on what is perceived as comfortable. Regarding comfort as something measurable, the preferred and actual temperature setting for most Swedish households, including those studied here, is somewhere between 18 and $23^{\circ} \mathrm{C}$, most people preferring $20-21^{\circ} \mathrm{C}$ (Gaunt 1985; Hallin 1989; Isaksson and Karlsson 2006; Lindén et al. 2006). These ranges are in line with the recommendations of the Swedish National Board of Health and Welfare (2005). An acceptable societal energy conservation strategy would accordingly be to encourage people to maintain home temperatures at the lower end of the preferred temperature range, i.e., 18$20^{\circ} \mathrm{C}$.

In the interview study, some of the respondents also kept the heat setting in this slightly lower interval, not mainly to save energy, but because they found it more comfortable or healthier. One respondent, who had the temperature set at 18 degrees, stated: 
If you are freezing, put on a cardigan. Seriously, you'll feel a lot better if it's not too hot. If it gets too hot, you get tired and lazy. (Folke BH)

Just as people can get used to and feel comfortable with higher indoor temperatures, the opposite is also true. For example, research into the domestication of passive houses (Isaksson 2009, 2011) demonstrates that some household members, who initially thought the indoor temperature felt too low, not only got used to the new indoor climate as time passed, but also re-evaluated it and ended up preferring it. In this case, the passive house technology, due to its limited heating ability, influenced how these respondents viewed indoor comfort. However, converting to district heating or bedrock heating systems does not limit the heating ability and does not seem to have the same favorable influence on the users' view of comfort. A more plausible interpretation is that those who preferred lower temperatures preserved their old preferences and habits related to indoor comfort, despite the system conversion.

Then, the examples demonstrate that since heating technologies may influence the household energy habits and comfort preferences in different ways the energy advice and support given to households should be accustomed to the characteristics of the various technologies. The study about indoor comfort in passive houses showed that what is regarded as comfort may change in an environmental friendly line after getting familiar with the new home. It showed that time is an important factor for the households to find out what their new heating system implies for their comfort - and energy consumption.

To pay attention to how various heating technologies influence the comfort preferences of households might be of significance since in recent decades, Western society seems to have moved towards views of comfort that entail escalating energy consumption (Shove, 2003). This change in the social norms of comfort is reflected by the following respondent who does not prefer to have it too warm indoors:

I try to keep it as cold as possible to save money, but it's not accepted anymore, so to speak. One should keep it at 20 degrees. (Sven BH)

Twenty degrees is not necessarily the temperature this respondent would like to have, but it is what is expected of him by his social context. Activities related to the project of creating a comfortable indoor environment, when guided by social norms, might lead to an increase in energy consumption, as Wilhite et al. (1996) demonstrated in relation to the socio-cultural importance of a warm, cosy house in Norway. Nevertheless, in the above statement, the respondent does not refer to what temperature he physically prefers, but instead to the need to save money, which is part of another significant project in households' everyday lives, that of managing operational costs.

\subsection{Activities related to the household economy}

When Swedish authorities and interest organizations direct general information towards household members to influence their energy-related activities, the message is often underpinned by economic arguments (Gyberg and Palm 2009) and the logic of cutting costs. Translated into the concrete use of the heating system, typical energy advice would run as follows: 
What is your preferred indoor temperature? Maybe it would be possible to lower the temperature one degree without feeling too cold. For homeowners, a one-degree increase in average temperature means around five per cent higher heating costs. (Swedish Energy Agency 2013, authors' translation)

Some people can translate this kind of information directly into action. Jakob (DH) said that, even though his family preferred it warm indoors, they tried to keep the temperature down "since every increase of one degree costs a lot of money". His household relates temperature-regulating activities to the project of managing expenses, more specifically, controlling operational costs within a restricted budget. In fact, the respondents talk about their energy use in terms of money spent rather than kilowatt hours, since the former makes much more sense from their perspective (see also Kempton and Montgomery 1982). From this perspective, the energy advice quoted above makes sense, since this is how energy use is translated in many people's everyday lives and contexts. Though operational costs are important to many respondents, the dilemma is that it is not easy to keep track of expenses in real time due to a lack of immediate feedback. There is no display in front of the heating system that provides information about the economic cost of the energy purchased by the household members when the temperature is increased or decreased one or two degrees. Instead, information about operational costs is received some months later when the bill is delivered. In this sense, when it comes to influencing the concrete use of the heating system, the "invisible" use of energy is replaced with the similarly invisible operational costs.

However, some respondents did carefully calculate, not their immediate, but their monthly use of energy in order to keep track of the operational costs of their new heating systems. Faced with the choice of a new heating system, the investment and annual costs were of great significance, especially for many of the respondents who converted to bedrock heat pumps: Would the investment cost eventually be repaid due to lower operational costs? When? Would they reduce their operational costs as much as was stated in the brochures? Although activities related to operational costs could lead to lower energy consumption, the opposite could also be true. Since the new system (compared with the old) was often found to be very efficient in terms of energy consumption, this resulted, as the rebound effect entails, in economic incentives to use it more:

With bedrock heating, it is so efficient, even though the winter has been cold. We often take baths and showers and the washing machine is running almost every day. So it feels like there is room to use energy. I do not have a bad conscience going up to 20 degrees because it is so cheap. (Filip BH)

Whether the ability to keep track of expenses in real time would change the views and habits of this respondent remains an open question. Instead, and as this statement indicates, the overall activities related to cutting operational costs have decreased in importance with the use of the new system. Consequently, the use of economic arguments to anchor energy-related information in the everyday life of this household has lost effectiveness.

\subsection{Learning how to handle information and technology}


A one-sided focus on operational costs in an information strategy intended to influence household members' energy-related activities seems to overlook issues related to the concrete management and understanding of the energy technology, i.e., projects concerning learning, system maintenance, and interest. This is confirmed in the literature examining householder technical learning and heating system maintenance, in which the results often highlight households' difficulties handling the technology and/or related information (Critchley et al. 2007; Isaksson 2009; Klintman et al. 2003; Lindén et al. 2006; Sernhed and Pyrko 2006; Smith and Pett 2005). For example, in a Swedish study, Sernhed and Pyrko (2006) found that most households were uncertain about how to operate their newly installed district heating systems, despite the instruction manual and other information provided. In another Swedish study, Klintman et al. (2003) found that district heating was regarded as less convenient and less simple to use than the households had expected.

In the present study, the respondents' engagement in activities related to learning about and maintaining the new heating system varied considerably. The fear of making mistakes was sometimes so great that it prevented people from engaging with the technology at all, whereas in other cases a possibly malfunctioning system could spur engagement in which respondents carefully monitored the system and spent substantial time and effort learning about the technology. Statements such as "I need to know about the system in case it malfunctions" (Johan BH) or that it was important to know about the technology and understand what is wrong "if something happens at night" (Tomas DH) illustrate the importance of understanding the heating system to prevent or mitigate future problems. In contrast to those who did not interact with the technology at all, these engaged respondents regarded themselves as active performers of activities related to learning and maintenance of the system. However, many respondents did not perform activities of any of these kinds. Instead, their participation was more modest and often revolved around elementary system features; if they found it necessary to deal with other aspects of the system, they called the company for assistance. Still, they needed to learn about these elementary features. ${ }^{5}$

Typical learning activities consisted of reading technical manuals, participating in short instruction sessions given by the installers, "carefully testing" the technology (e.g., by changing the temperature setting to discern how it affected the indoor temperature), and, finally (engaged in by a few), actively participating in system installation. The first two learning activities are especially interesting in the context of this article, since they rely on either written or oral information instruments intended to facilitate technical learning and system maintenance. As illustrated by the following quotations in particular, the written instructions were difficult to translate into the household context:

Those who have written this [technical manual] are very technically competent and cannot quite understand our situation - we don't deal with this every day. (Eva DH)

and

\footnotetext{
${ }^{5}$ An in-depth analysis of how the respondents learned to handle the renewable heating system is presented in "Learning for lower energy consumption" (Isaksson 2014).
} 
They take people who know as their starting point, not people who don't know. (Bo BH).

The written instructions that came with the heating system were often found to be too extensive and technically complicated, lacking relevant precision and simplicity. Consequently, these instructions, intended to facilitate technical learning and system maintenance, might instead exert a constraining effect. If both the manual and the technology are perceived as difficult to understand, how is it possible to learn how to handle the heating system?

From a learning perspective, one way to deal with such uncertainty is to follow explicit advice, such as written and oral information about the new subject to be learned (e.g., Berner 2009; Blaye et al. 1999). For the inexperienced, receiving explicit but straightforward information is a first step towards understanding the technology, and it often makes people confident enough to try using certain of its features.

In fact, in the interviews the qualities of precision and simplicity were discussed by the households when the technician first installed the new heating system. The installer's oral instructions often consisted of a demonstration of the key systemrelated activities, such as how to put more water into the system and regulate the temperature. This information exchange often became an important resource for the respondents' system management. However, relying too much on this single instruction session also generated problems in cases in which respondents thought the oral instructions covered all they had to know. For example, if the instructions were slightly incorrect or important functions of the technology were not discussed, this caused frustration and in a few cases technical problems. Like the consequences of the instruction manual discussed above, an instruction session in which the information was poorly conveyed insufficiently supported learning how to handle the technology.

As the literature highlights, household lack of control and difficulties handling technology are ultimately obstacles to reducing energy consumption (Lindén et al. 2006; Smith and Pett 2005). Consequently, improving information about and support in how to use the technology might be among the first factors to consider in order to facilitate the translation of energy-related information. However, to learn how to handle the technology, might not be a top priority in the daily lives of households.

\subsection{Activities as a hobby - and the non-interest in heating activities}

In general, the heating system is not the focal point of peoples' everyday lives. Instead, the users' relationship with such semi-automatic systems might be characterized as a background relationship: the technology should be working somewhere in the background, without much call for attention (Ihde 1990). Respondent comments such as "I have never looked at it" (Olof DH) or "I'm useless at that, but then, I'm not that interested either" (Bo BH) illustrate such a relationship with the technology.

Such a background relationship does not advance energy conservation. The tendency not to bother at all about the technology and leave it to run on its own could, as 
Klintman et al. (2003) state, cause the system to work at sub-optimal efficiency. ${ }^{6}$ In addition, this relationship with the technology likely hampers the translation of energy-related information. It might be quite difficult for the information to reach the households if engaging with the technology is completely absent from their everyday lives.

Thus, one solution is to shift the perception of the technology: from being regarded as something uninteresting in the background, the heating system could become an important foreground technology that, since it is energy consuming, should be controlled. In the interview study, examples of the latter kind of perception are found among the people who converted to bedrock heat pumps. Some of these respondents clearly enjoyed interacting with their heating systems, regarding it more or less as a hobby. For example, one of them said that he spent "every evening, every day, every minute" (Johan BH) with the technology at the beginning, while another mentioned that he started a "bedrock heat club" at work (Rolf $\mathrm{BH}$ ), in which participating colleagues compared settings and temperatures.

Although one cannot expect everyone to be as involved as these respondents were, how they described their activities during the interviews reveals some features that are probably important in increasing peoples' engagement. First, their activities build on a self-confident attitude when interacting with these systems that emphasizes the significance of learning how to handle the technology. Second, they are involved because they enjoy their system-related activities or regard them as important. This calls for developing various innovative strategies for stimulating engagement, revolving around the need for system maintenance, environmental concerns, comfort, monetary savings, or social networks such as the "bedrock heat club". Third, a major reason for the interest described by these and other respondents was the system's novelty - it was a new machine in their home to be examined and handled. A similar conclusion was drawn by Isaksson (2009) in her research into heating system domestication. In the first year when the technology was new, the household members were more engaged with and interested in the technology and more eager to learn about it. Such an observation suggests that, for many users, the background relationship seems to emerge in a later phase.

Although most respondents would not define these activities in the early phase of use as a hobby, their slightly greater initial interest and involvement probably facilitated the process of translating energy conservation information and support due to the greater presence of the technology in their everyday lives. In addition, the household might be more open to influence from information in this phase, since everyday routines and indoor temperature preferences have not yet stabilized, making this a strategic time to prevent potentially wasteful behaviours from taking root.

\section{Discussion and conclusions}

As highlighted in the literature, information instruments aiming to promote energy efficiency and conservation at the household level must be comprehensive and consistent with household members' own experiences, daily activities, and

\footnotetext{
${ }^{6}$ The study by Klintman et al. (2003) about household members' reasoning about their choice of heating system revealed similar tendencies among some respondents who converted to district heating.
} 
responsibilities (e.g., Bartiaux 2008; Darby 2006). Otherwise, such information will not be found relevant and will not be transformed into action.

This article has examined how people understand and define energy-related activities as parts of everyday projects with a particular focus on the constraints on energy conservation. This approach emphasizes the factors that guide people in their everyday lives as well as the factors that should be more thoroughly considered to support the translation of energy-related information and its adaptation to household members' own experiences. The article treated household use of renewable heating systems as a case and demonstrated that household members' heating related activities also were related to overall projects concerning household budgeting, a comfortable and convenient daily life, learning and/or maintaining about home technologies, hobbies, and reducing environmental impact. Information and support that better fit households' everyday life context should be produced e.g. information that correspond to the relevant projects connected to the actual use of the heating technology and incorporate what creates meaning for the involved individuals.

It is important to consider the broad range of projects related to the heating activities. Information instruments focusing solely on one or two relevant projects do not sufficiently address the goals of household projects or, hence, the full range of heating-related activities. This not only limits the number of people who might be interested in or able to access the information, but might also hamper the process of translating energy-related information and support due to the interrelatedness of the heating-related activities. For example, to manage the heating system cost effectively (which relates to the household budget balance project) and to reduce environmental impact (which relates to the project of reducing the environmental impact), household members must know how to operate the technology (which relates to the technical learning and system maintenance needed in order to take control of the technology).

Consequently, energy information instruments would benefit from focusing on helping people overcome the difficulties encountered in attaining goals related to their various projects (e.g., reducing operational costs, maintaining acceptable indoor comfort, and learning about and maintaining the technology) while keeping activities connected to energy efficiency and conservation at the top of the agenda. This also means addressing various factors not necessarily accounted for in energy conservation support, such as the suppliers ability to adjust the text in the technical manuals to households with no or limited technical interest, households' fear of making mistakes, or lack of interest in the technologies. When developing appropriate information and support, treating the household members' activities and reasoning as the departure point increases the awareness of potential constraints on energy conservation and informs policy makers of the need to carefully consider the socio-technical context in which energy-consuming activities take place. The growing use of more energy-efficient technologies might encourage new habits and perceptions of the everyday use of energy that make the currently most common motive for saving energy (such as lowering operational cost) less potent.

Still, how is the suggested anchoring of energy-related information and support supposed to affect the households? In general, Swedish households have good opportunities to gain information about and support in reducing their energy consumption. Websites administered by relevant authorities and companies inform 
households of the value of changing behaviour and technology to become more energy efficient (Gyberg and Palm 2009). In addition, energy consultants are employed by municipalities and subsidized by the state whose job is to "disseminate objective knowledge of environmentally friendly energy sources, energy distribution and energy use", in particular, to Swedish households (Palm 2010, p 2858).

Although these efforts to disseminate information and support to households are beneficial (e.g., most households must be able to access the support), they are limited when it comes to affecting the daily doings and strivings of households. Rather than being integrated into the projects and activities of everyday life, these efforts tend to give rise to a separate project "educating oneself about energy efficiency". This is too narrow a project.

Instead, energy-related information and support ought to be embedded in the everyday lives of households and in their various activities and projects. For example, learning about and maintaining heating systems might imply strengthening the installers' and hence the heating system companies' obligation to educate households, while simultaneously strengthening households' responsibility to implement key activities in connection with their heating systems (Isaksson 2014). At the same time, energy counselling should be provided by professionals who understand the systems in question. This also applies to the various learning and maintenance artefacts (e.g., instruction manuals), which should include information about how to reduce energy consumption and should be developed in line with the users' understanding of their heating systems.

Critics may argue that the broad-ranging integration of energy-related information and support would interfere too much with the private lives of households, and these concerns are not without foundation. For example, Palm (2010), who analysed how Swedish energy consultants informed households about energy-efficient behaviour and the energy-efficient technology available on the market, concludes that advice on technology choice was a more common and more "comfortable" type of advice to give, since information on energy-consuming behaviour interfered more with the private lives of households.

Nevertheless, it might not be the information per se that is socially unacceptable, but the societal organizational project of the energy authorities and consultants informing households about these issues. Probably, information about and support in how to conserve energy might work better if it is formulated with households' everyday projects and the activities related to them as point of departure rather than to energy in itself. In this article we have pointed at some projects of the kind that can serve as a starting point for developing such a strategy. This claims for energy authorities and consultants to gain more knowledge about everyday projects in households. If this is done, information could prove to be a useful instrument to promote the widerranging reorganization of societal institutions in a sustainable direction.

\section{Acknowledgements}

This research is part of the programme Sustaining Everyday Life - Information instruments for sustainable resource use in households based on daily activity pattern analysis, funded by the Swedish Research Council Formas. 


\section{References}

Abrahamse, W., Steg, L., Vlek, C., \& Rothengatter, T. (2005). A review of intervention studies aimed at household energy conservation. Journal of Environmental Psychology, 25(3), 273-291.

Aune, M. (2007). Energy comes home. Energy Policy, 35(11), 5457-5465.

Bartiaux, F. (2008). Does environmental information overcome practice compartmentalisation and change consumers' behaviours? Journal of Cleaner Production, 16(11), 1170-1180.

Berner, B. (2009). Learning control: Sense-making, CNC machines and changes in vocational training for industrial work. Vocations and Learning, 2, 177-194.

Blaye, A., Ackermann, E., \& Light, P. (1999). The relevance of relevance in children's cognition. In J. Bliss, R. Säljö, \& P. Light (Eds.), Learning sites: Social and technological resources for learning (pp. 120-132). Oxford: Elsevier Science Ltd.

Bruel, R., \& Hoekstra, J. (2005). How to stimulate owner-occupiers to save energy? eceee 2005 Summer Study proceedings: Energy savings - What works and who delivers? Panel 6, 1197-1204.

Christoff, P. (1996). Ecological modernization, ecological modernities. Environmental Politics, 5(3), 476-500.

Critchley, R., Gilbertson, A., Grimsley, M., \& Green, G. (2007). Living in cold homes after heating improvements: Evidence from Warm-Front, England's home energy efficiency scheme. Applied Energy, 84(2), 147-158.

Darby, S. (2006). Social learning and public policy: Lessons from an energy-conscious village. Energy Policy, 34(17), 2929-2940.

Dryzek, J. (2005). The politics of the earth: Environmental discourses. Oxford: Oxford University Press.

Druckman, A., \& Jackson, T. (2008). Household energy consumption in the UK: A highly geographically and socio-economically disaggregated model. Energy Policy, 36(8), 3177-3192.

Ellegård, K. (1999). A time-geographical approach to the study of everyday life of individuals: A challenge of complexity. GeoJournal, 48(3), 167-175.

Ellegård, K. (2001). Att hitta system i den välkända vardagen. En tankeram för studier av vardagens aktivitetsmönster och projekt. In: K. Ellegård \& E. Wihlborg (Eds.), Fånga vardagen: Ett tvärvetenskapligt perspektiv [Capturing everyday life: An interdisciplinary perspective] (pp. 41-66). Lund, Sweden: Studentlitteratur [in Swedish].

Erickson, R. (1997). Paper or Plastic? Energy, Environment and Consumerism in Sweden and America. Westport Connecticut: Praeger Publishers.

Gatersleben, B., Steg, L., \& Vlek, C. (2002). Measurement and determinants of environmentally significant consumer behavior. Environment and Behaviour, 34(3), 335-362.

Gaunt, L. (1985). Bostadsvanor och energi- om vardagsrutinernas inverkan på energiförbrukningen $i$ elvärmda småhus. [Living habits and Energy -Everyday routines and their effects on energy consumption in electrically heated single-family homes]. Gävle, Sweden: Statens Institut för byggnadsforskning [in Swedish].

Goffman, E. (1986 [1974]). Frame Analysis. Boston: Northeastern University Press. 
Gram-Hanssen, K. (2013). Efficient technologies or user behaviour, which is the more important when reducing households' energy consumption? Energy Efficiency, 6(3), 447-457.

Gyberg, P., \& Palm, J. (2009). Influencing households' energy behaviour: How is this done and on what premises? Energy Policy, 37(7), 2807-2813.

Henning, A. (2005). Equal couples in equal houses: Cultural Perspectives on Swedish Solar and BioPellet Heating Design. In Guy, S., Moore, S (Eds.) Sustainable Architectures: Cultures and Natures in Europe and North America.

Hallin, P.-O. (1989). Tid för omställning - om hushållens anpassningsstrategier vid en förändrad energisituation. [Time for change - Households' adaptation strategies in a changing energy situation.]. Lund, Sweden: Lund University [dissertation in Swedish].

Herring, H. (2006). Energy efficiency: A critical view. Energy, 31(1), 10-20.

Herring, A., \& Sorell, S. (Eds.) (2009). Energy efficiency and sustainable consumption: The rebound effect. Basingstoke, UK: Palgrave Macmillan.

Hägerstrand, T. (1970). What about people in regional science? Regional Science, 24, 6-21.

Hägerstrand, T. (1985). Focus on the corporeality of man, society and environment: The science and praxis of complexity. Tokyo: The United Nations University.

Ihde, D. (1990). Technology and the lifeworld: From garden to earth. Bloomington and Indianapolis, IN: Indiana University Press.

Isaksson, C. (2009). Uthålligt lärande om värmen? Domesticering av energiteknik i passivhus. [Sustainable learning about indoor heating?] Linköping, Sweden: Linköping University, Department of Thematic Studies, Technology and social change [dissertation in Swedish].

Isaksson, C. (2011). From an active to a passive house. In B. Moshfegh (Ed.), Proceedings of the World Renewable Energy Congress, Linköping Sweden, 8-13 May 2011.

Isaksson, C. (2014). Learning for lower energy consumption. International Journal of Consumer Studies, 38(1), 12-17.

Isaksson, C., \& Karlsson, F. (2006). Indoor climate in low-energy houses: An interdisciplinary investigation. Building and Environment, 41(12), 1678-1690.

Jonsson, D.K., Gustafsson, S., Wangel, J., Hojer, M., Lundqvist, P., \& Svane, O. (2011). Energy at your service: Highlighting energy usage systems in the context of energy of efficiency analysis. Energy Efficiency, 4(3), 355-369.

Kempton, W., \& Montgomery, L. (1982). Folk quantification of energy. Energy - The International Journal, 7, 817-828.

Klintman, M., Mårtensson, K., \& Johansson, M. (2003). Bioenergi för uppvärmning Hushållens perspektiv. Lund, Sweden: Lund University, Department of Sociology [in Swedish].

Lindén, A.-L., Carlsson-Kanyama, A., \& Eriksson, B. (2006). Efficient and inefficient aspects of residential energy behaviour: What are the policy instruments for change? Energy Policy, 34(14), 1918-1927.

Mahapatra, K., \& Gustavsson, L. (2009). Influencing Swedish homeowners to adopt district heating system. Applied Energy, 86(2), 144-154. 
Mahapatra, K. \& Gustavsson, L. (2008). Innovative approaches to domestic heating: Homeowners' perceptions and factors influencing their choice of heating system. International Journal of Consumer Studies, 32, 75-87.

Mårtensson, W. \& Fredriksen, S. (2005). Effektiv marknadsföring av småhusfjärrvärme. [Effective marketing of district heating in detached homes]. Lund, Sweden:, Lund University [in Swedish].

Palm, J. (2010). The public-private divide in household behavior: How far into home can energy guidance reach? Energy Policy, 38(6), 2858-2864.

Palmborg, C. (1986). Social habits and energy consuming behaviour in single-family houses. Stockholm: Swedish Council for Building Research.

Pyrko, J. \& Darby, S. (2011). Conditions of energy efficient behavior: A comparative study between Sweden and the UK. Energy Efficiency, 4(3), 393-408.

Sernhed, K., \& Pyrko, J. (2006) Småhusägarnas syn på att köpa fjärrvärme. [Homeowners’ view of buying district heating]. Stockholm: Swedish District Heating Association.

Shove, E. (2003). Comfort, cleanliness and convenience: The social organization of normality. Oxford: Berg.

Shove, E. (2004). Efficiency and consumption: Technology and practice. Energy and Environment, 15(6), 2004.

Skill, K. (2008). (Re)creating ecological action space: Households' activities for sustainable development in Sweden. Linköping, Sweden: Linköping University, Department of Thematic Studies, Technology and Social Change.

Smith, W., \& Pett, J. (2005). Energy efficiency refurbishment programmes help, but are the end-users doing their bit? eceee 2005 Summer Study proceedings: Energy savings - What works and who delivers? Panel 5, 957-968.

SOU (2008). Vägen till ett energieffektivare Sverige: Slutbetänkande av

Energieffektiviseringsutredningen. [The path to a more energy efficient Sweden: Final Report of Energy Efficiency Inquiry]. Stockholm: SOU 2008:110 (State Official Report) [in Swedish].

Spaargaren, G. (2000). Ecological modernization theory and domestic consumption. Journal of Environmental Policy \& Planning, 2(4), 323-335.

Spaargaren, G., \& Van Vliet, B. (2000). Lifestyles consumption and the environment: The ecological modernization of domestic consumption. Environmental Politics, 9(1), 50-76.

Swedish Energy Agency (2013). Energispartips värme [Energy advice: heat]. http://www.energimyndigheten.se/sv/Hushall/Tips-pa-hur-du-spar-energi--/Varme/ Accessed 30 September 2013 [in Swedish].

Swedish National Board of Health and Welfare (2005). Temperatur inomhus. [Indoor temperatures] SOSFS 2005:15. Stockholm: Socialstyrelsen [in Swedish].

Swedish Parliament (2009). En sammanhållen klimat- och energipolitik - Energi.[An integrated climate and energy policy- Energy]. Proposition 2008/09:163, Stockholm [in Swedish]

Wilhite, H., Hidetoshi, N., Masuda, T., Yamaga, Y. \& Haneda, H. (1996). A cross-cultural analysis of household energy use behaviour in Japan and Norway, Energy Policy 24, 795-803. 
Wilhite, H., \& Lutzenhiser, L. (1999). Social loading and sustainable consumption. Advances in Consumer Research, 26, 281-287.

Wilhite, H., \& Nilsson, H. (2008). Breaking out of the efficiency box. Energy Efficiency, 1(2), 105106.

Winther, T., \& Ericson, T. (2013). Matching policy and people? Household responses to the promotion of renewable electricity. Energy Efficiency, 6(2), 369-385. 